\title{
GENETICS OF MELIBIOSE FERMENTATION IN SACCHAROMYCES ITALICUS VAR. MELIBIOSI
}

\author{
C. ROBERTS, A. T. GANESAN and W. HAUPT \\ Carlsberg Laboratory, Copenhagen, Denmark
}

\section{INTRODUCTION}

Received $16 . i \mathrm{ii} .59$

THE problem of genic control of sugar fermentation by the yeasts has. been investigated in considerable detail during the past twenty years. Lindegren, Spiegelman and Lindegren (1944) were the first to investigate the genetics of melibiose fermentation by producing hybrids between $S$. carlsbergensis, which ferments melibiose, and $S$. cerevisiae, which is a melibiose non-fermenter. Their tetrad analysis yielded a 2-gene segregation, and they concluded that $S$. carlsbergensis possesses two dominant genes for melibiose fermentation and $S$. cerevisiae, the recessive alleles. Another hybrid between the same two species was. analysed by Spiegelman, Lindegren and Lindegren (1945) and Io asci yielded only $2: 2$ segregation ratios, indicating that the parent strain $S$. carlsbergensis must have contained only one gene for melibiase synthesis. The authors also studied the adaptive nature of melibiose fermentation: when the cultures from the same Io asci were maintained in the presence of melibiose, 6 of them were found to yield $4: 0$ ratios and then to revert to the original $2: 2$ ratios upon the removal of melibiose from the substratum. This phenomenon was explained on the basis of enzymatic synthesis and cytoplasmic transfer in the absence of the gene ; confirmation of these results has not been obtained. Winge and Roberts ( 1957) likewise studied melibiose fermentation, but because of the low fertility of their original hybrid, they were unable to determine whether $S$. carlsbergensis contains more than one Me-gene. On the other hand, Gilliland (1956), as a result of tetrad analyses of a hybrid between $S$. carlsbergensis and $S$. cerevisiae var. ellipsoideus concluded that only one melibiase gene was present.

Yeasts which possess one or more of the R-genes for the synthesis: of $\beta$-h-fructosidase are able to ferment raffinose by splitting off the fructose portion of the molecule, which is in turn fermented by the zymase (hexokinase) system present in all fermenting yeasts; the remaining melibiose portion of the molecule is left intact, providing that the melibiase gene is absent. In the presence of $\mathrm{Me}$, the melibiose is split into galactose and glucose. The raffinose molecule can also be fermented by a completely different process in the absence of the R-gene. In the single spore progeny of the hybrid $S$. carlsbergensis $\times$ a recessive, Winge and Roberts (1957) found that those isolates which lacked the R-gene were nevertheless able to ferment raffinose $\mathrm{I} / 3$ due to the complementary action of $\mathrm{Me}$ and $\mathrm{G}$ (galactozymase gene). The former acted on the galactosidic linkage, liberating galactose 
and sucrose, while the G-gene brought about the customary fermentation of galactose. Thus, $\mathrm{I} / 3$ raffinose fermentation results when either

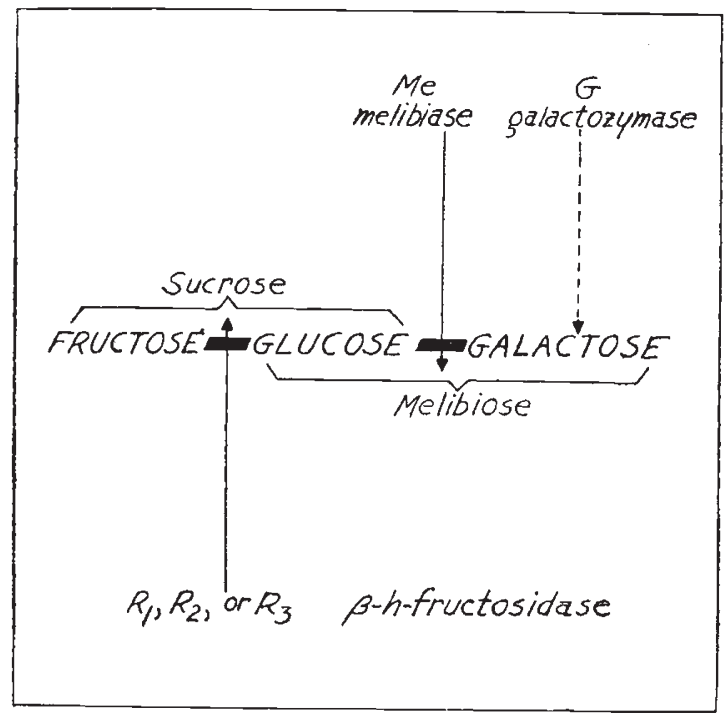

Text-Fig. I.-Gene action involved in the hydrolysis and fermentation of the raffinose molecule (after Winge and Roberts, 1957).

$\mathrm{R}$ or $\mathrm{Me}+\mathrm{G}$ is present, whereas when all three genes are present, as in $S$. carlsbergensis, the molecule is fermented completely (text-fig. I).

TABLE I

A comparison of the fermentative ability and genotype of the three different yeasts under discussion

\begin{tabular}{|c|c|c|c|}
\hline Yeast & & $\begin{array}{c}\text { Fermentative } \\
\text { ability }\end{array}$ & Genes present \\
\hline S. carlsbergensis & . $\quad$. & $\begin{array}{l}\text { Raffinose }+(\mathrm{I} / \mathrm{I}) \\
\text { Sucrose }+ \\
\text { Melibiose }+ \\
\text { Galactose }+ \\
\text { Maltose }+\end{array}$ & $\begin{array}{l}R_{2} \text { (and perhaps others) } \\
R_{2} \\
M e \text { (and perhaps others) } \\
G \\
M_{6} \text { (and perhaps others) }\end{array}$ \\
\hline S. italicus & $\cdot$ & $\begin{array}{l}\text { Raffinose- } \\
\text { Sucrose- } \\
\text { Melibiose- } \\
\text { Galactose + } \\
\text { Maltose + }\end{array}$ & $\begin{array}{l}\mathrm{r} \\
\mathrm{r} \\
\mathrm{me} \\
\mathrm{G} \\
\mathrm{M}\end{array}$ \\
\hline S. italicus var. melibiosi & & $\begin{array}{l}\text { Raffinose }+(\mathrm{I} / 3) \\
\text { Sucrose - } \\
\text { Melibiose }+ \\
\text { Galactose }+ \\
\text { Maltose }+\end{array}$ & $\begin{array}{l}\mathrm{r} \\
\mathrm{r} \\
\mathrm{Me}(?) \\
\mathrm{G}(?) \\
\mathrm{M}(?)\end{array}$ \\
\hline
\end{tabular}


This demonstration of the role played by complementary genes in the fermentation of raffinose was based on a genetic investigation and was fully confirmed by the biochemical study of Losada (1957), who demonstrated that the melibiase found in $S$. carlsbergensis is capable of hydrolysing the raffinose molecule. A similar conclusion with regard to $S$. italicus was independently reached by van Uden and Assis-Lopes (1957) who worked with strains isolated from the digestive tract of both man and horse. These strains differed from the standard description of the species (Lodder and Kreger-van Rij, r952) in being able to ferment melibiose and raffinose $\mathrm{I} / 3$ and were therefore relegated to a new variety, $S$. italicus var. melibiosi. As seen from table r, which lists the distinguishing characters of these different yeasts, the findings of van Uden and Assis-Lopes raise several interesting questions. In the first place, is melibiase synthesis in S. italicus var. melibiosi governed by a single gene or by polymeric genes, and, secondly, is this gene(s) identical with the Me-gene of $S$. carlsbergensis? Of added interest would be a comparison of the genetics of maltose and galactose fermentation in these two yeasts.

\section{MATERIALS AND METHODS}

For the purpose of investigating these problems a request for cultures was sent to Dr van Uden in Lisbon, who kindly supplied us with the following three strains of his new variety :

26r 3. From human fæces. Our Number 5 ro

2624. From horse cæcum. Our Number 5 I I

2625. From human fæces. Our Number 512.

In the work reported herein, Cultures 5 I 0 and 5 I I were employed together with the homozygous recessive single spore culture 303-9, which was descended from hybridisations involving $S$. chevalieri, $S$. italicus and $S$. carlsbergensis (Winge and Roberts, 1957) and which contained the recessive genes for the synthesis of melibiose, $\beta$-hfructosidase, and maltase, and the "slow" gene for the synthesis of galactozymase (mermg ${ }_{s}$ ).

For sporulation, Fowell's sodium acetate agar (Fowell, 1952) was employed with excellent results. Isolations of the single spores, as well as hybridisation experiments, were performed with the aid of a Zeiss gliding micromanipulator according to the standard Carlsberg isolation technique (Winge, 1935). The cultures were maintained in 8 per cent. Pilsner wort, which was also used for isolation work. The various sugars employed in the fermentation tests were added to yeast water at a concentration of 2 per cent. with the exception of raffinose, which was employed at 4 per cent. concentration. Qualitative fermentation tests on young dextrosegrown cultures were carried out singly in either Einhorn or Winge fermentometers, and when the sugar to be tested was melibiose, the cells were washed in sterile tap water and centrifuged before the analyses. In doubtful cases, the test was repeated and often rechecked in the van Iterson-Kluyver fermentometer, which was also employed for all quantitative determinations of fermentative ability.

In the test for melibiose fermentation, 1 c.c. of 2 per cent. melibiose yeast water was added to the culture immediately after washing, since it was noted that the time interval between washing and first contact with melibiose in the fermentometer could influence the readings, especially if this period was not of uniform duration for all cultures. When fermentation analyses are to be made on a large number of tetrads, it is most convenient to wash and centrifuge as many cultures as possible at the same time; this necessarily results in a considerable lapse of time 
between the completion of the first and the last analysis, during which the cells are suspended in a small amount of tap water. Since any considerable prolongation of time between washing and contact with melibiose may retard the onset of fermentation as much as several days, the addition of melibiose to the washed cells was found to be necessary. In this procedure, the amount of fermentation occurring before the suspended culture was placed in the fermentometer was found to be negligible. With respect to the fermentation analyses, it was also found to be advantageous in some cases to hasten the onset of fermentation by the addition of small amounts of dextrose (Spiegelman and Dunn, 1947 ; Suomalainen, Axelson and Oura, 1956). To ten parts of yeast water containing 2 per cent. of the sugar to be tested was added one part of 2 per cent. dextrose yeast water. This relatively small amount of dextrose was not capable of yielding visible evidence of fermentation when inoculated with a yeast culture, but in combination with another sugar, it clearly hastened the fermentation of the latter. Whenever mixtures of sugars were employed, fermentation medium lacking dextrose was also employed as a control.

In the tetrad analyses, asci showing abnormal segregation were infrequently encountered, but since they represented only a very small proportion of the total number analysed, they have been omitted from the tables and disregarded in determination of genotype.

\section{EXPERIMENTAL RESULTS}

\section{(i) Analysis of 510 (human strain)}

The giant colony of the original strain of 5 io presented a smooth surface apparently devoid of sectoring (plate I, fig. 2), while its single spore cultures segregated out in the form of dissimilar giant colonies, indicating that 5 50 was heterozygous. With respect to cellular morphology, a $2: 2$ segregation was found in 6 tetrads, half of the single spore cultures being composed of long cells and half of round-oval cells (plate I, figs. 6, 7). This is undoubtedly the same phenomenon already reported by Ditlevsen (I944) in a strain of $S$. italicus isolated from wine must. Single spore cultures from another 3 asci were then tested for their ability to ferment melibiose: all I2 cultures were fermenters. This absence of segregation indicated that (I) 5 Io was homozygous with respect to the melibiase gene (MeMe) or (2) 5 Io was either homozygous or heterozygous with respect to a number of polymeric melibiase genes.

It was decided to commence the hybridisation work with a selfdiploidised single spore culture of 5 I o capable of fermenting melibiose, rather than with $5^{\text {Io }}$ itself. This would of course make it impossible to answer the question "How many melibiase genes does 5 I o have?", but in view of the possible complexity of the problem as indicated by (2) above, it was thought wiser first to determine how many genes are present in a melibiose-fermenting segregant. For this purpose the single spore culture $5^{\text {Io- } 6}$ was chosen. It was long-celled and capable of fermenting melibiose, maltose and galactose. In order to be sure that this culture was normal with respect to homozygosity, it was brought to sporulation and 8 spores from two asci were isolated; the resulting single spore cultures were found to be identical with respect to cellular morphology, appearance of the giant colony, and melibiose fermentative ability. 
(a) Hybrid 352. The first hybridisation attempts involved 24 crossings between $5^{10-6}$ and the recessive $303-9$, resulting in the production of only one hybrid ( $\mathrm{H}_{352}$ in text-fig. 2), which, as was to be expected, was itself capable of fermenting melibiose, maltose and galactose. Sucrose was not fermented. In appearance, it resembled more $5^{\text {10-6 }}$ than $303-9$ (plate I, fig. I).

\section{0}

S. italicus var. melibiosi

(Human Strain)

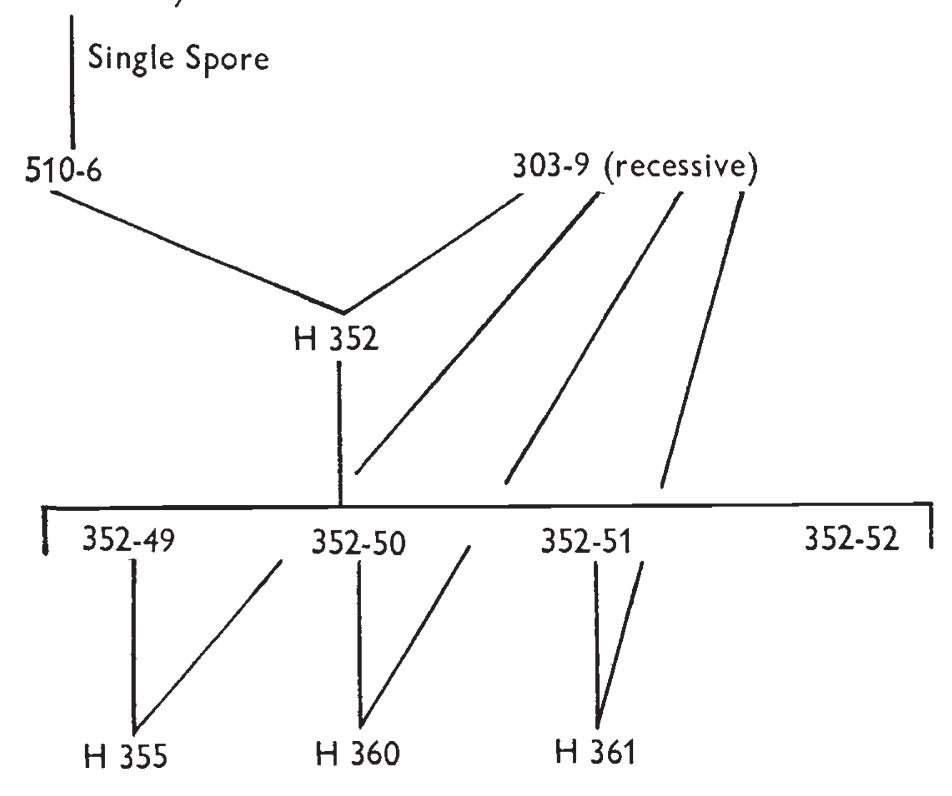

TEXT-FIG. 2.-The crossing experiments carried out for the purpose of determining the number of Me-genes in the single spore, $510-6$.

Hybrid $35^{2}$ possessed considerable fertility, the percentage of spore germination being $82 \cdot 5$. Thirty asci were dissected, and of these, 2I yielded complete tetrads. Sixteen were analysed for the ability to ferment maltose, and a $2: 2$ ratio was obtained in each ascus. This showed that only a single gene for maltase synthesis was present in 5 I0-6. Seven of the 21 asci were analysed for galactose fermentation and as all yielded a $2: 2$ ratio, it appeared reasonably certain that 5 10-6 contained the G-gene. With respect to melibiose fermentation, however, the results were quite different. Ten asci segregated out as $4: 0,10$ as $3: 1$, and one as $2: 2$, making a total of only $14 \cdot 3$ per cent. non-fermenters. Expressed as percentages, there were $47 \cdot 6$ per cent.$4: 0,47 \cdot 6$ per cent. $-3: \mathrm{r}$, and $4 \cdot 8$ per cent.-2 $: 2$, as compared with the theoretical 3 -gene segregation ( $5^{\circ}$ per cent. crossing over) of $5^{2 \cdot 8}$ per cent.-4:0, 44.4 per cent.-3: 1 , and 2.8 per cent.-2:2, which 
comprises 12.5 per cent. non-fermenters. Although this agreement was sufficiently close to warrant the assumption that $5^{\text {I0- }} 6$ contained 3 polymeric Me-genes, it was evident that final proof of the assumption could be obtained only from backcrosses.

In the backcrossing experiments it was decided to attempt hybridisations between the recessive 303-9 and all of the single spore cultures of one of the 2 I tetrads already analysed, since it was expected that this method would result in the most complete genetic analysis possible. If, for example, a 3 : i ascus of $\mathrm{H}_{32}$ is chosen for backcrossing, and it is assumed that $3 \mathrm{Me}$-genes are present heterozygotically in $\mathrm{H}_{352}$, then the 4 ascospores (I-IV) of this tetrad could be expected to contain 2, 2, 2, and o Me-genes or 3, 2, I, and o Me-genes, as, e.g. in the following arrangement :*

I

$\mathrm{Me}_{1} \mathrm{Me}_{2} \mathrm{Me}_{3}$
II

$\mathrm{Me}_{1} \mathrm{me}_{2} \mathrm{Me}_{3}$
III

$\mathrm{me}_{1} \mathrm{Me}_{2} \mathrm{me}_{3}$
IV

$\mathrm{me}_{1} \mathrm{me}_{2} \mathrm{me}_{3}$

$\mathrm{A}_{3}$ : $\mathrm{I}$ ascus from $\mathrm{H}_{3} 5^{2}$ was chosen for this study; its 4 single spore cultures were designated $352-49,-50,-5$ I and -52 , of which 52 alone was unable to ferment melibiose.

(b) Backcross Hybrid 355. Eight crossing attempts were made between the recessive 303-9 and 352-49, which was able to ferment only melibiose and maltose, and one of these resulted in Hybrid 355 (textfig. 2). Eighteen asci were dissected, and of these, 9 gave complete tetrads; the spore germination percentage of $\mathrm{H} 355$ was 83 . Melibiose fermentation analyses of these 9 asci resulted in only $2: 2$ ratios, indicating that 352-49 must have had only one melibiase gene, as Spore III above. Maltose fermentation tests also yielded a $2: 2$ segregation, as expected.

(c) Backcross Hybrid 360 . This hybridisation between the recessive 303-9 and 352-50, which fermented melibiose, maltose and galactose, proved to be difficult; only one zygote was obtained out of a total of 52 spore pairings. This was designated Hybrid 36o (text-fig. 2), and its spore germination percentage was found to be 78 . Only io complete asci were recovered from 24 dissected ones. Eight of them gave a $3:$ I segregation with respect to melibiose fermentation, while the 2 remaining ones gave $4: 0$. This is in substantial agreement with a 2-gene segregation (5o per cent. crossing over), which theoretically would yield $6 \cdot 7-3: 1,1 \cdot 7-4: 0$ and $1 \cdot 7-2: 2(66 \cdot 7$ per cent $: 16 \cdot 7$ per cent. : $16 \cdot 7$ per cent.). It is therefore concluded that the melibiose fermenting 352-5o contained 2 Me-genes, as Spore II above. Both the maltose and the galactose fermentation analyses yielded $2: 2$ segregation ratios in all Io asci; these genetic markers demonstrate not only that one gene was present in 352-50 for maltase and one for galactozymase, but also that $\mathrm{H}_{360}$ was a true hybrid.

* Here as well as in what follows the numerical subscripts of the different genes are arbitrarily chosen. 
One of the 4 : o asci of $\mathrm{H}_{3} 6$ o (360-1 3 to i 6 ) was selected for further study of the comparative fermentative ability of its 4 single spore cultures. Since it was known that two different Me-genes were distributed among these 4 spores, then 2 of them must contain the one gene, and 2, the other. Furthermore, this tetrad segregated out as $2: 2$ with respect to galactose fermentation, as follows :

$$
\begin{aligned}
360 \text { - I3 } & \mathrm{Me}_{1} \mathrm{~g}_{\mathrm{s}} \\
\text { - I } 4 & \mathrm{Me}_{1} \mathrm{G} \\
\text { - I5 } & \mathrm{Me}_{2} \mathrm{G} \\
\text { - I6 } & \mathrm{Me}_{2} \mathrm{~g}_{\mathrm{s}}
\end{aligned}
$$

Quantitative raffinose and melibiose analyses were performed in the van Iterson-Kluyver fermentometer. The results showed that $360-14$ and $360-15$ fermented melibiose completely (due to the presence of the G-gene), while $360-13$ and $360-16$ fermented melibiose partially (due to the absence of the G-gene). Raffinose was fermented only by 360-I 4 and 360-I5, since $360-13$ and $360-16$, although capable of hydrolysing the raffinose molecule, were unable to ferment it. After fermentation had taken place in a van Iterson-Kluyver fermentometer inoculated with $360-14$ and containing raffinose yeast water, the sugar solution was tested chromatographically. By employing $n$-butanolacetic acid as a solvent and $p$-anisidine- $\mathrm{HCl}$ as a spraying agent (Block, Le Strange and Zweig, I $95^{2}$ ), it was found that the solution contained only sucrose. These chromatographic tests, in conjunction with the quantitative fermentation analyses, provide complete confirmation of the biochemical studies of Losada (1957) and the genetic studies of Winge and Roberts (i957) on the fermentation of raffinose by complementary gene action.

(d) Backcross Hybrid $36 r$. Now if our assumption is correct that 510-6 contained 3 Me-genes, and knowing that 352-49 contained I Me-gene, that $35^{2-50}$ contained 2 Me-genes, and that $35^{2-52}$ is unable to ferment melibiose, then $35^{2-5^{I}}$ must be similar to Spore I (p. 504) and contain all three Me-genes.

The hybridisation between the recessive $303-9$ and $35^{2-5} \mathrm{I}$, which fermented melibiose and galactose, proved to be the most difficult of all. Only one crossing was successful out of 74 attempts; the resulting

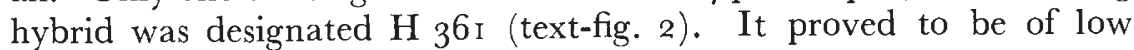
fertility, only 48 per cent. of its spores germinating. Twelve complete tetrads were recovered out of a total of 52 dissected. These yielded with respect to melibiose fermentation 6-4:o and 6-3: 1 , and it is concluded that this is representative of the 3 -gene segregation with 50 per cent. crossing over (theoretically, 6.3-4:0, 5.3-3: I and $0 \cdot 3-$ $2: 2)$; the agreement is actually very close, in view of the small number of asci analysed. With respect to galactose fermentation, all $\mathrm{I} 2$ asci yielded the expected $2: 2$ segregation ratio.

(e) Conclusions. The results obtained above are summarised in table 2, where it will be seen that the genetic formulas of the 4 single 


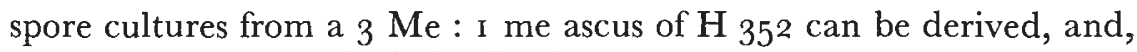
furthermore, that their derivation is in accord with theoretical expectation based on Mendelian law. Since three different polymeric genes for the synthesis of melibiase have been found to be present in one single spore from 5 Io, it can be concluded that van Uden's human strain of Saccharomyces italicus v. melibiosi contains at least 3 polymeric Me-genes, which have been designated $\mathrm{Me}_{1}, \mathrm{Me}_{2}$ and $\mathrm{Me}_{3}$. No evidence for the presence in this strain of more than one gene either for maltase or galactozymase synthesis was obtained.

TABLE 2

Table showing the method employed in determining the genotypes of the four singlespore cultures of the tetrad $352-49,-50,-51$ and -52

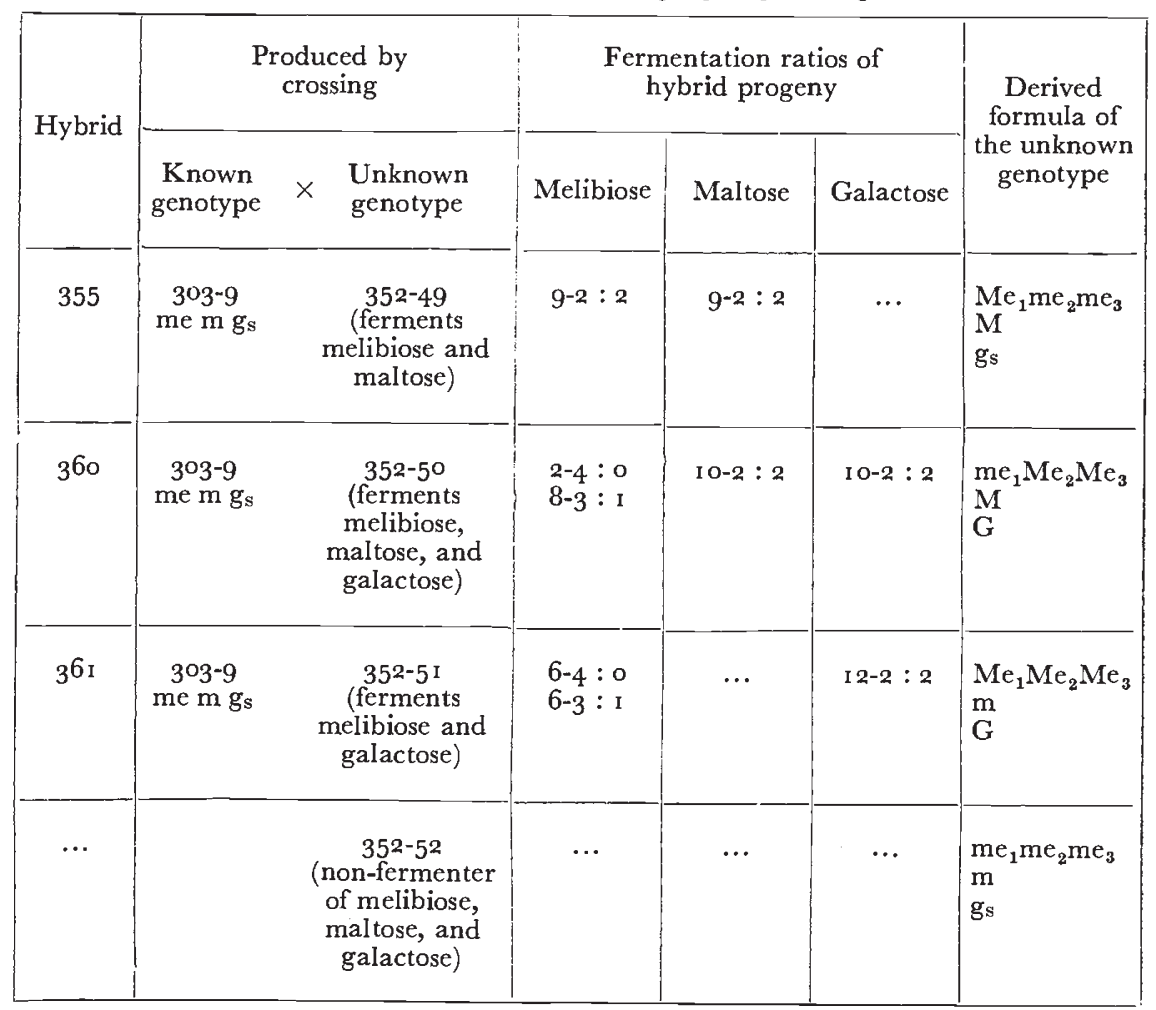

\section{(ii) Analysis of 511 (horse strain)}

The original culture of 5 I I yielded a smooth giant colony without visible sectoring (plate I, fig. 4), while its single spore cultures gave rise to different types of giant colonies, indicating the heterozygous nature of the original culture. In contrast to the segregation in cellular morphology exhibited by the human strain, the horse strain and all of its single spore progeny were composed of round-oval cells. Actively growing cultures of $5^{11}$ did, however, include a small number of cells which enlarged considerably and then burst, indicating that some 
physiological abnormality must be present in the strain. It can be mentioned here that subsequent investigations with single spores of 5II (to be described below) revealed three different manifestations of the bursting phenomenon : (I) an isolated spore swells considerably and eventually bursts (plate I, fig. 5), (2) an isolated spore germinates by the formation of an abnormal protuberance whose few attached buds eventually burst, and (3) an isolated spore germinates to form a normal colony of hundreds of cells, a few of which burst.

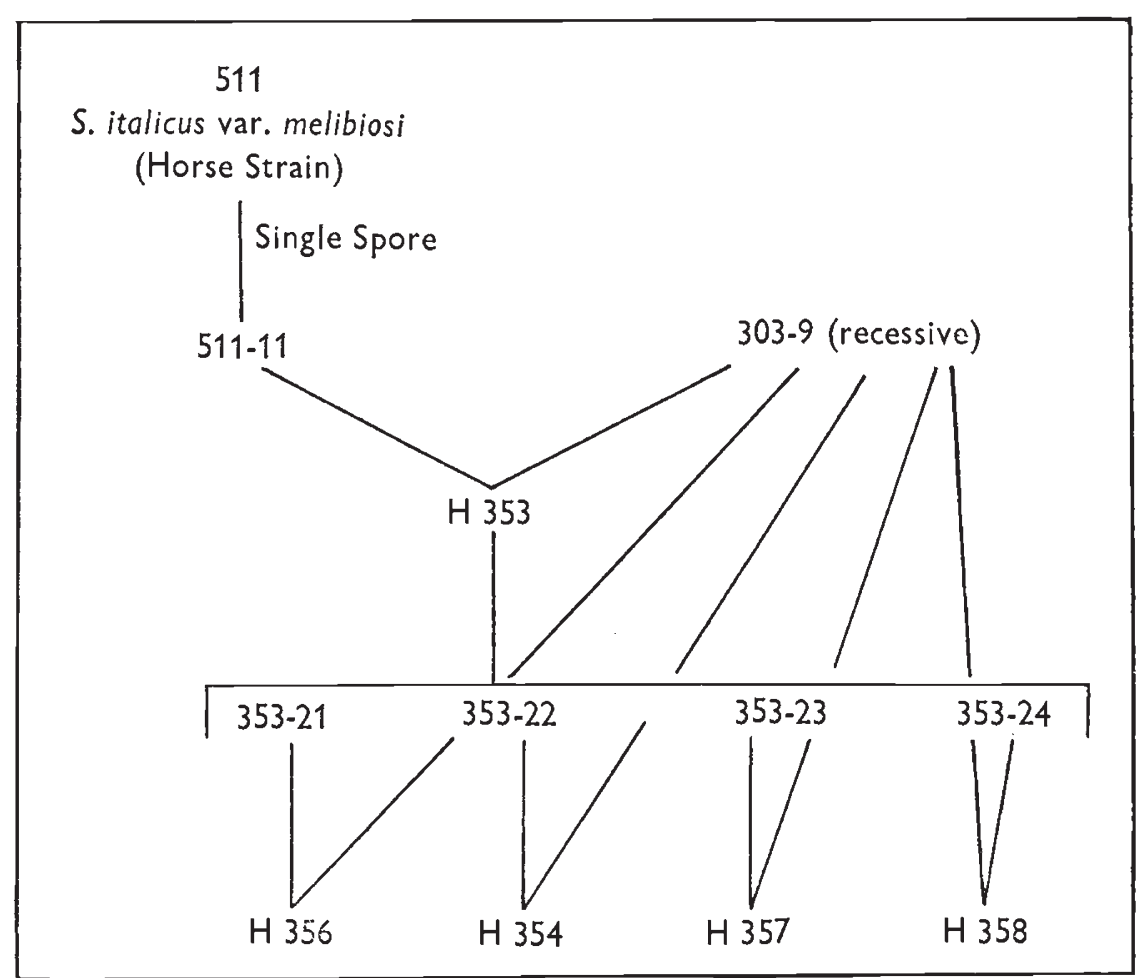

TEXT-FIG. 3.-A portion of the hybridisations necessary for gene number determination in the single spore, 5I I-I I.

Preliminary experiments on segregation of fermentation characters were made on the cultures from 3 tetrads: galactose fermentation yielded 3-2:2 ratios, maltose fermentation $2-3: 1$ and $1-4: 0$, and melibiose, 12 fermenters. In the light of our experience with the human strain, these results indicated that the fermentation of melibiose, as well as maltose, by $5^{\mathrm{I} I}$ was likewise governed by polymeric genes. It was also found that all 12 single spore cultures were capable of sporulation, probably due to the presence of the D-gene for diploidisation (Winge and Roberts, 1949).

(a) Preliminary hybridisations. Initial crossings were attempted between the original culture of $5 \mathrm{II}$ and the recessive 303-9 and led to the production of 2 hybrids, $\mathrm{H}_{349}$, with a spore germination percentage of 68 , and $\mathrm{H}_{350}$, with a spore germination percentage of 73 . 
Tetrads derived from both hybrids yielded the following segregation ratios with respect to melibiose : $\mathrm{H}_{349}, \mathrm{I} 3-4$ : o and $\mathrm{H} 350,22-4$ : o and $I-3: I$. The fact that only one recessive culture was found among I 44 tested indicated that the polymeric gene system occurring in 5 I I may include a greater number of genes than are present in $5 \mathrm{IO}$. If, for example, 5 freely segregating Me-genes were present, then one would expect to find one recessive out of every 32 fermenters.

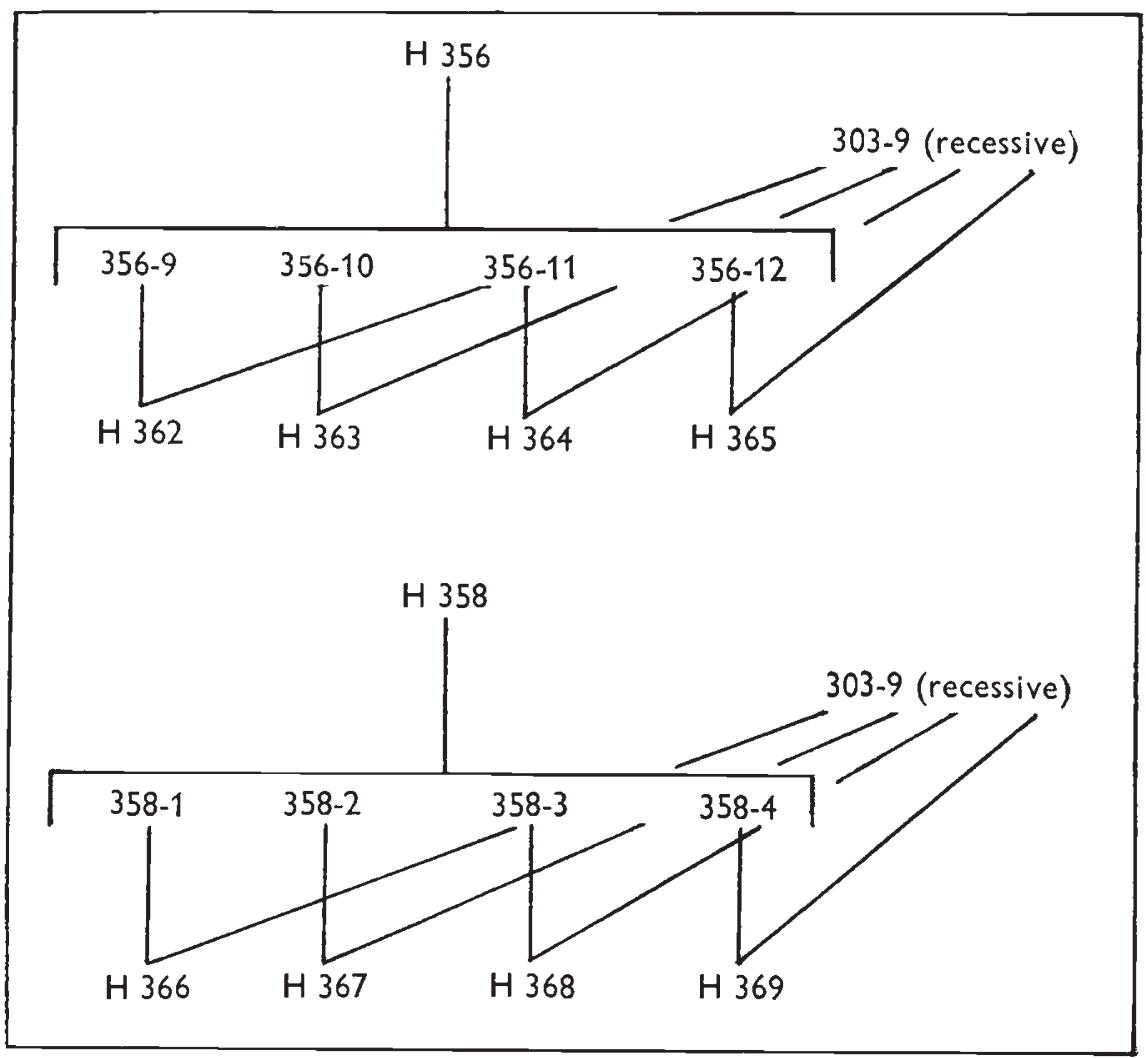

TEXT-FIG. 4.-Hybridisations necessary for gene number determination in $\mathrm{H} 35^{6}$ and $\mathrm{H}_{35^{8}}$.

Since a lower frequency of recessives actually was obtained in these preliminary analyses, it was assumed that the melibiase gene system in 5 I I must be of considerable complexity. For this reason, it was decided that, just as in the study of $5 \mathrm{Io}$, it would be advisable first to determine the number of genes present in a single spore segregant of 5II. For this purpose was chosen the diploid homozygous 5II-II, a single spore culture which sporulated abundantly and which fermented melibiose, maltose and galactose. In order to be sure of the homozygous nature of this culture, 2 tetrads derived from it were analysed and were found to possess the parental characters with respect to fermentative ability and giant colony appearance. 


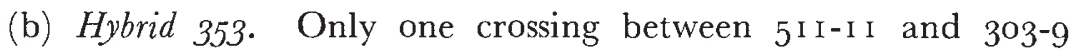
was successful out of 2 I attempts. The resulting hybrid was designated $\mathrm{H} 353$ (text-fig. 3), and it can be seen from fig. 3 of plate I that it resembled most the dominant parent. It was capable of fermenting melibiose, maltose and galactose and its spore germination percentage was 73 .

Fourteen complete asci were recovered from a total of 40 dissected, and all $5^{6}$ spores were able to ferment melibiose. That the hybrid itself was normal was shown by the $2: 2$ ratios obtained in 13 asci for both maltose and galactose segregation; one ascus was abnormal, giving a 3 : I ratio for both maltose and galactose. The lack of segregation with respect to melibiose was unexpected, since it indicated that $5 \mathrm{II}-\mathrm{I}$, just as the original $5 \mathrm{II}$, must contain a number of melibiase genes. It was therefore necessary to analyse a complete ascus of $\mathrm{H}_{353}$ by attempting to backcross each of the 4 fermenting single spore cultures to the recessive in order to determine how many Me-genes each contained. For this purpose the ascus containing Spores 353-2 I, $-22,-23$ and -24 was selected (text-fig. 3); of these 4 single spore cultures, No. 22 appeared to ferment melibiose more slowly than the others.

(c) Analysis of Ascus 353-2I to 24. Spore 353-2I (ferments melibiose and galactose). Eighteen crossing attempts between $353-2$ I and the recessive 303-9 resulted in one hybrid, $\mathrm{H} 356$, which was capable of fermenting melibiose and galactose and which had a spore germination percentage of 65 . Ten complete asci from $\mathrm{H}_{35} 6$ were analysed for melibiose and galactose fermentation and yielded ratios of 5-4:0, 4-3: I and I-2:2 for melibiose and I0-2:2 for galactose. This segregation ratio for melibiose was in close agreement with the theoretical 3-gene segregation $(5 \cdot 3-4: 0,4 \cdot 4-3:$ I and $0 \cdot 3-2: 2)$, but in order to obtain additional confirmation of the existence of 3 melibiase genes in Spore 21, the following experiment was designed: From $\mathrm{H} 356$ a 4 : o ascus was chosen for further hybridisation studies which would consist in backcrossing each of its 4 single spore cultures to the recessive for the purpose of determining whether $\mathrm{H}_{35} 6$ actually had segregated out 3 genes in this ascus. If this proved to be the case, then the existence of 3 genes in Spore 2 I would be confirmed.

Accordingly, the ascus 356-9, - I0, - I I and - 12, whose 4 single spore cultures all fermented melibiose, was selected (text-fig. 4). The details of the hybridisations are presented in table 3 , where it will be seen that all 4 single spore cultures were not only able to hybridise successfully with the same recessive type but also that the hybrids possessed a high degree of fertility. These facts indicate that in this material the mating type system is either masked by the possible existence of the D-gene or is completely absent (Winge and Roberts, I958).

With respect to melibiose fermentation, $\mathrm{H}_{362}$ yielded a 2-gene segregation (8-3: I, I-4:o and 3-2:2 + I abnormal o:4), $\mathrm{H}_{363}$ yielded a $\mathrm{I}$-gene segregation $(9-2: 2+\mathrm{I}$ abnormal $\mathrm{o}: 4)$ and $\mathrm{H} 364$, 
$9-2: 2$. Segregations of $2: 2$ for galactose fermentation were obtained. from $\mathrm{H}_{3} 6_{2}$ and $\mathrm{H}_{3} 6_{3}$. Now the fact that of the 4 spores to be tested.

TABLE 3

Hybridisations undertaken between a recessive and each of the four spores from one ascus for the purpose of determining the number of Me-genes in Spore 2I

\begin{tabular}{|c|c|c|c|c|c|c|}
\hline Parents & $\begin{array}{c}\text { Crosses } \\
\text { attempted }\end{array}$ & $\begin{array}{c}\text { Crosses } \\
\text { successful }\end{array}$ & $\begin{array}{c}\text { Resulting } \\
\text { hybrid }\end{array}$ & $\begin{array}{c}\text { Hybrid } \\
\text { asci } \\
\text { dissected }\end{array}$ & $\begin{array}{c}\text { Tetrads } \\
\text { obtained }\end{array}$ & $\begin{array}{c}\text { Spore } \\
\text { germination } \\
\text { per cent. }\end{array}$ \\
\hline $356-9 \times 303-9$ & 18 & $\mathbf{I}$ & $\mathrm{H}_{362}$ & 17 & 12 & 85 \\
$356-10 \times 303-9$ & 6 & $\mathbf{H}$ & $\mathrm{H}_{363}$ & 12 & 10 & 95 \\
$356-11 \times 303-9$ & 8 & $\mathbf{1}$ & $\mathrm{H}_{364}$ & 14 & 9 & 86 \\
$356-12 \times 303-9$ & 8 & $\mathbf{I}$ & $\mathrm{H}_{365}$ & 17 & 11 & 76 \\
\hline
\end{tabular}

Nos. 9, Io and I I appeared to contain 2, I and I Me-genes respectively indicates that the remaining spore (I2) must contain $2 \mathrm{Me}$-genes if

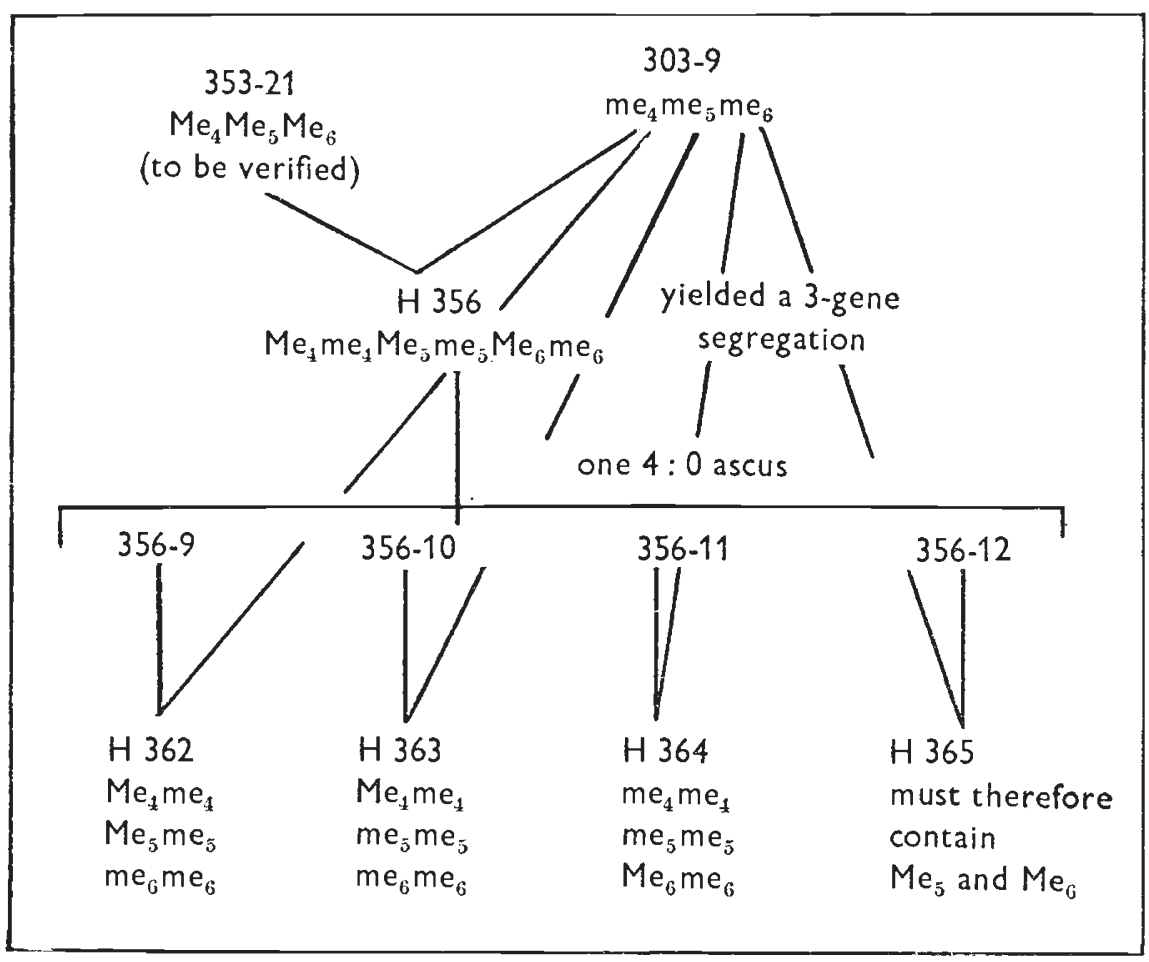

TEXT-FIG. 5.-Derivation of the number of Me-genes present in $\mathrm{H}_{3} 65$.

the assumption that $353-2$ I contained 3 genes was correct. This is illustrated diagrammatically in text-fig. 5. Upon analysing the 
progeny of $\mathrm{H}_{3} 65$, confirmation of the existence of $3 \mathrm{Me}$-genes in 353-2 I was obtained by the fact that $\mathrm{H}_{3} 6_{5}$ itself gave a 2-gene segregation ( 8 asci yielded a $3:$ I ratio and 3 , a $4: 0$ ratio). These results also demonstrate that a genetic analysis of only io tetrads from $\mathrm{H}_{35} 6$ was actually sufficient to determine accurately the number of $\mathrm{Me}$-genes present in Spore $2 \mathrm{I}$.

Spore 353-22 (ferments melibiose). From text-fig. 3 it can be seen that $\mathrm{H} 354$ was produced by hybridising $353-22$ with the recessive. This hybrid, which had a spore germination percentage of 66 , fermented melibiose but neither galactose nor maltose. Eight tetrads were analysed with respect to melibiose fermentation, and all yielded a 2:2 segregation, showing that only one Me-gene was present in Spore 22.

Spore 353-23 (ferments melibiose, maltose and galactose). Twelve crosses were attempted between $353-23$ and 303-9, resulting in 2 hybrids. The first which was analysed showed no segregation with respect to maltose and galactose, indicating that the hybrid was not a true one, most probably due to some abnormality at the time of spore copulation. Furthermore, its spore germination percentage was only 47 , and many spores and cells were observed to swell and burst.

Theother hybrid, which was designated $\mathrm{H}_{357}$ (text-fig. 3) had a spore germination percentage of $67 \cdot 5$. Twenty-two tetrads were analysed, of which 3 were abnormal with respect to segregation ratios for one or more of the 3 sugars and were discarded. Fifteen asci, however, gave I-gene segregations for both maltose and galactose. Nineteen asci yielded the following ratios with respect to melibiose fermentation : I I-3: I and 8-4: o. In contrast to the segregation from $\mathrm{H}_{35} 6$, this segregation is neither characteristic of a 2-gene nor a 3-gene segregation. It resembles most, however, the latter (theoretically, $8 \cdot 4-3:$ I and $10-4: 0)$, and Spore 23 was therefore assumed to have $3 \mathrm{Me}$-genes.

Spore 353-24 (ferments melibiose and maltose). If we are correct in assuming that the first 3 spores $(2 \mathrm{I}, 22,23)$ of the tetrad $353-2 \mathrm{I}$ to 24 contain 3 , I and 3 Me-genes respectively, then we can calculate in advance how many genes should theoretically be expected to occur in Spore 24, and, consequently, the number of genes in 5I I-I I (textfig. 3). It was found that an even number of genes could not be present in Spore 24 (since the total number of Me-genes in the tetrad must be divisible by 2), but that I, 3, 5 or 7 genes were possible. One possible gene arrangement is shown in table 4 , which at the same time indicates the relationship between gene number in Spore 24 and in Spore 5 I I-I I. Expressed in another way, if the hybrid arising from the cross Spore $24 \times$ the recessive yields a I-gene segregation for melibiose, then

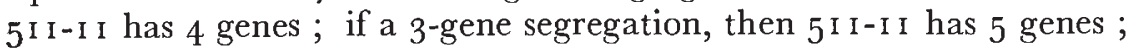
5 -gene segregation, 6 genes ; and 7-gene segregation, 7 genes.

A hybrid was produced between the single spore culture arising from Spore 24, 353-24, and the recessive and was designated as $\mathrm{H} 35^{8}$ 
(text-fig. 3). Its spore germination percentage was 69, and 9 complete tetrads were obtained. These were analysed with respect to melibiose fermentation and all 36 cultures were capable of fermentation. Although this result was a strong indication of the presence of many Me-genes in Spore 24, nothing more definite could be deduced from it. It was therefore again necessary to backcross a complete tetrad of $\mathrm{H}_{35}^{8}$ and analyse all 4 hybrids in the usual way in order to determine gene

TABLE 4

Relationship between gene number in Spore 24 and in Spore 5II-II

\begin{tabular}{|c|c|c|c|c|c|}
\hline Spore & $\begin{array}{c}\text { No. of } \\
\text { Me-genes }\end{array}$ & $\begin{array}{l}5 \text { II-II with } \\
4 \mathrm{Me} \text {-genes }\end{array}$ & $\begin{array}{l}5 \mathrm{II} \text {-I I with } \\
5 \mathrm{Me} \text {-genes }\end{array}$ & $\begin{array}{l}5 \mathrm{II}-\mathrm{II} \text { with } \\
6 \mathrm{Me} \text {-genes }\end{array}$ & $\begin{array}{l}5 \text { Ir-I I with } \\
7 \text { Me-genes }\end{array}$ \\
\hline $\begin{array}{l}21 \\
22 \\
23 \\
24\end{array}$ & $\begin{array}{c}3 \\
\mathrm{r} \\
\text { To be } \\
\text { determined }\end{array}$ & $\begin{array}{l}\mathrm{Me}_{4} \mathrm{Me}_{5} \mathrm{Me}_{6} \mathrm{me}_{7} \\
\mathrm{Me}_{4} \mathrm{me}_{5} \mathrm{me}_{6} \mathrm{me}_{7} \\
\mathrm{me}_{4} \mathrm{Me}_{5} \mathrm{Me}_{6} \mathrm{Me}_{7} \\
\mathrm{me}_{4} \mathrm{me}_{5} \mathrm{me}_{6} \mathrm{Me}_{7} \\
\therefore \text { I gene in } \\
\text { Spore } 24\end{array}$ & $\begin{array}{l}\mathrm{Me}_{4} \mathrm{Me}_{5} \mathrm{Me}_{6} \mathrm{me}_{7} \mathrm{me}_{8} \\
\mathrm{Me}_{4} \mathrm{me}_{5} \mathrm{me}_{6} \mathrm{me}_{7} \mathrm{me}_{8} \\
\mathrm{me}_{4} \mathrm{me}_{5} \mathrm{Me}_{8} \mathrm{Me}_{7} \mathrm{Me}_{8} \\
\mathrm{me}_{4} \mathrm{Me}_{5} \mathrm{me}_{6} \mathrm{Me}_{7} \mathrm{Me}_{8} \\
\therefore 3 \text { genes in } \\
\quad \text { Spore } 24\end{array}$ & $\begin{array}{c}\mathrm{Me}_{4} \mathrm{Me}_{5} \mathrm{Me}_{6} \mathrm{me}_{7} \mathrm{me}_{8} \mathrm{me}_{9} \\
\mathrm{me}_{4} \mathrm{me}_{5} \mathrm{me}_{6} \mathrm{me}_{7} \mathrm{me}_{8} \mathrm{Me}_{9} \\
\mathrm{me}_{4} \mathrm{me}_{5} \mathrm{me}_{6} \mathrm{Me}_{2} \mathrm{Me}_{8} \mathrm{Me}_{9} \\
\mathrm{Me}_{4} \mathrm{Me}_{5} \mathrm{Me}_{6} \mathrm{Me}_{7} \mathrm{Me}_{8} \mathrm{me}_{8} \\
\therefore \text { 5genes in } \\
\text { Spore } 24\end{array}$ & $\begin{array}{c}\mathrm{Me}_{4} \mathrm{Me}_{5} \mathrm{Me}_{6} \mathrm{me}_{7} \mathrm{me}_{8} \mathrm{me}_{9} \mathrm{me}_{10} \\
\mathrm{me}_{4} \mathrm{me}_{5} \mathrm{me}_{6} \mathrm{Me}_{7} \mathrm{me}_{8} \mathrm{me}_{9} \mathrm{me}_{10} \\
\mathrm{me}_{4} \mathrm{me}_{5} \mathrm{me}_{6} \mathrm{Me}_{7} \mathrm{Me}_{8} \mathrm{Me}_{9} \mathrm{Me}_{10} \\
\mathrm{Me}_{4} \mathrm{Me}_{5} \mathrm{Me}_{6} \mathrm{Me}_{7} \mathrm{Me}_{8} \mathrm{Me}_{8} \mathrm{Me}_{10} \\
\therefore \text { genes in } \\
\text { Spore } 24\end{array}$ \\
\hline
\end{tabular}

number in Spore 24. The details of the hybridisations are presented in table 5; here again the success of the crossing attempts confirms the absence of a functional mating system in this material.

Spore 358-I (ferments melibiose). The spore germination of $\mathrm{H}_{3} 66$ (text-fig. 4) was complicated by the bursting phenomenon. In 43 of the 72 asci 2 of the spores swelled and then burst, whereas the 2 remaining spores germinated normally. In only 3 asci did all 4 spores

TABLE 5

Hybridisations undertaken between a recessive and each of the four spores from one ascus for the purpose of determining the number of Me-genes in Spore 24

\begin{tabular}{|c|c|c|c|c|c|c|}
\hline Parents & $\begin{array}{c}\text { Crosses } \\
\text { attempted }\end{array}$ & $\begin{array}{c}\text { Crosses } \\
\text { successful }\end{array}$ & $\begin{array}{c}\text { Resulting } \\
\text { hybrid }\end{array}$ & $\begin{array}{c}\text { Hybrid } \\
\text { asci } \\
\text { dissected }\end{array}$ & $\begin{array}{c}\text { Tetrads } \\
\text { obtained }\end{array}$ & $\begin{array}{c}\text { Spore } \\
\text { germination } \\
\text { per cent. }\end{array}$ \\
\hline $358-1 \times 303-9$ & 30 & I & H 366 & 72 & 3 & 48 \\
$358-2 \times 303-9$ & 26 & I & $\mathrm{H} 367_{36}$ & 24 & 10 & 72.4 \\
$358-3 \times 303-9$ & I2 & I & H 368 & 3 I & 13 & 67 \\
$358-4 \times 303-9$ & 8 & I & H 369 & 43 & 2 I & 68.8 \\
\hline
\end{tabular}

germinate normally. In the remaining 26 asci, incomplete germination or cell bursting, or both, occurred.

The 3 complete tetrads yielded a $2: 2$ segregation with respect to melibiose. Neither maltose nor galactose gene markers occurred in this hybrid. Sixteen spore cultures derived from 8 incomplete asci were also analysed, but no indication was found of linkage between melibiose fermentation and the bursting phenomenon.

On the basis of these few data, we assume that Spore I contains only one gene for melibiase synthesis. 
A few experiments were carried out ${ }^{*}$ on the effect of increased osmotic pressure on the bursting phenomenon in the spores. Dissections of asci of $\mathrm{H} 366$ were performed in ro different concentrations of dextrose yeast water ranging from 3-12 per cent.; 3 asci were dissected in each concentration. Concentrations up to and including Io per cent. were unable to prevent bursting, while the only effect of II and I 2 per cent. concentrations was that the swollen spores remained intact for a longer period of time ( 48 hours or more) before their ultimate collapse. No indication of budding was observed in the swollen spores.

Spore 358-2 (ferments melibiose and maltose). Hybrid 367 (text-fig. 4) was produced by crossing $35^{8-2}$ and $303-9$ and had a spore germination percentage of $72 \cdot 4$. The ro complete asci which were analysed yielded a 2-gene segregation $(6-3: 1,3-4: 0$ and $I-2: 2)$ for melibiose fermentation and a clear $2: 2$ segregation for maltose fermentation. Spore $35^{8-2}$ is thus assumed to possess 2 different Me-genes.

Spore 358-3 (ferments melibiose and maltose). Hybrid 368 (textfig. 4) was produced by crossing $35^{8-3}$ and 303-9 and had a spore germination percentage of 67 . The i3 complete asci which were analysed yielded 6-3: $1,6-4: 0$ and $\mathrm{I}-2: 2$ for melibiose fermentation and only $2: 2$ segregations for maltose fermentation. Although the melibiose segregation ratios obtained were not typical, they showed more resemblance to the theoretical 3-gene segregation than to any other, and for this reason it was assumed that Spore 358-3 contained 3 different Me-genes.

Spore $35^{8-4}$ (ferments melibiose). If the above determinations of gene number are correct, then the first 3 spores of the ascus (358- 1 , $-2,-3$ ) contain $\mathrm{I}, 2$ and $3 \mathrm{Me}$-genes respectively. On the basis of these determinations, the last spore $\left(35^{8-4}\right)$ could contain only 2,4 or 6 genes, yielding 4-, 5- and 6-gene segregations respectively.

Hybrid 369 (text-fig. 4) was produced between $35^{8-4}$ and $303-9$ and had a spore germination percentage of $68 \cdot 8$. The 22 complete asci which were analysed for melibiose fermentation ability yielded I 6-4 : o and 6-3: i segregations. This result, while at once eliminating the possibility of either 2 or 6 genes, as mentioned above, demonstrates the presence of 4 genes in Spore 358-4. The theoretical 4-gene segregation ( 50 per cent. crossing over) would consist of $16 \cdot 6-4: 0$, and $5 \cdot 3-3: \mathrm{I}$, and the agreement is thus nearly perfect.

The derived genotypes of the 4 spores from the single $4: 0$ ascus of $\mathrm{H} 35^{8}$ can now be written, for example, as :

$$
\begin{array}{cl}
\text { 358- } & \mathrm{Me}_{4} \mathrm{me}_{5} \mathrm{me}_{6} \mathrm{me}_{7} \mathrm{me}_{8} \\
35^{8-2} & \mathrm{Me}_{4} \mathrm{Me}_{5} \mathrm{me}_{6} \mathrm{me}_{7} \mathrm{me}_{8} \\
35^{8-3} & \mathrm{me}_{4} \mathrm{me}_{5} \mathrm{Me}_{6} \mathrm{Me}_{7} \mathrm{Me}_{8} \\
35^{8-4} & \mathrm{me}_{4} \mathrm{Me}_{5} \mathrm{Me}_{6} \mathrm{Me}_{7} \mathrm{Me}_{8}
\end{array}
$$


Knowing that 5 genes are thus present in $\mathrm{H} 35^{8}$, the Spore $353^{-24}$ must necessarily have contained the same 5 genes, since it was crossed with the recessive to produce $\mathrm{H}_{35}$ (text-fig. 3). And knowing that 353-24 contains 5 genes, then $\mathrm{H} 353$ must necessarily have contained 6 genes, as shown in text-fig. 6 . Finally, we are in a position to state that because $\mathrm{H} 353$ has 6 genes, then these same genes must also have been present in the Spore 5 I I-II.

(d) Conclusions. The genetic analyses reported above, the results of which are in full agreement with Mendelian law, demonstrate that van Uden's horse strain of $S$. italicus var. melibiosi contains at least 6 different polymeric genes for the synthesis of melibiase. These have

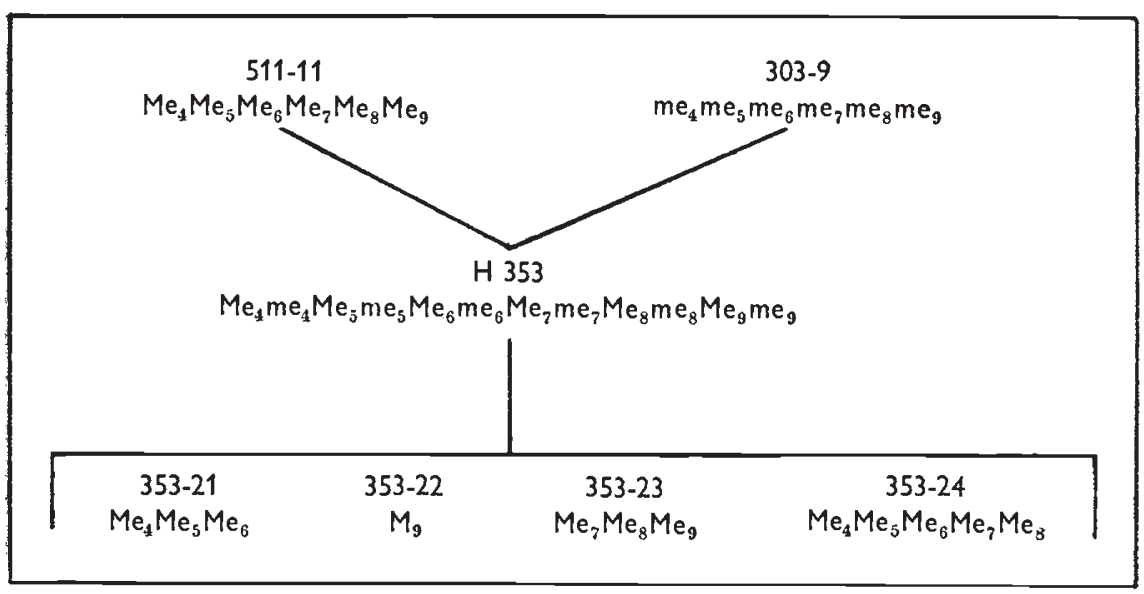

TEX -FIG. 6.-Derivation of the number of Me-genes in $\mathrm{H}_{353}$ and the single Spore, 5 I I-I I.

been designated $\mathrm{Me}_{4}, \mathrm{Me}_{5}, \mathrm{Me}_{6}, \mathrm{Me}_{7}, \mathrm{Me}_{8}$ and $\mathrm{Me}_{9}$, since it is not yet known whether any of them are identical with the $\mathrm{Me}_{1}, \mathrm{Me}_{2}$ and $\mathrm{Me}_{3}$ genes present in the human strain. No evidence for the presence of more than one gene for the synthesis of galactozymase was obtained, but the strain appears to have more than one gene for the synthesis of maltase.

\section{DISCUSSION}

This study was prompted by two unanswered questions : (I) How many melibiase genes are present in S. italicus var. melibiosi? and (2) Is the one melibiase gene present in $S$. carlsbergensis identical with one of the genes in S. italicus var. melibiosi ? These questions have not been answered. The elucidation of the genetics of melibiose fermentation in this yeast was found to be both a laborious and difficult task due to the existence of polymeric genes in the material. On the basis of several hundred tetrads we have, however, been able to demonstrate ( $\mathrm{I}$ ) that the human strain of $S$. italicus var. melibiosi contains at least 3 freely segregating Me-genes, (2) that the horse strain of S. italicus var. melibiosi contains at least 6 apparently unlinked Me-genes, (3) that the mechanism of raffinose hydrolysis in the absence of $\beta$-h-fructosidase 
is precisely the same in both $S$. italicus var. melibiosi and $S$. carlsbergensis, and (4) that there is no evidence in either strain for the existence of polymeric genes involved in the fermentation of galactose, but that it is likely that the horse strain contains more than one gene for the synthesis of maltase.

It is interesting to compare the genic differences among the yeasts under consideration, which are listed, together with their habitats, in table 6. It should not be overlooked, however, that it is theoretically possible for the human strain to contain the same number of Me-genes as the horse strain ; in the present state of our knowledge we can only be sure that the former contains at least 3 . Since these polymeric Me-genes segregate out in crosses, we know that they must be situated

TABLE 6

The yeasts under discussion compared with respect to habitat and number of melibiase genes present

\begin{tabular}{|c|c|c|c|}
\hline Yeast & & Primary habitat & $\begin{array}{l}\text { Number of melibiase } \\
\text { genes present }\end{array}$ \\
\hline S. carlsbergensis & . & $\begin{array}{l}\text { Grape must and juice, bottom } \\
\text { fermentation in breweries }\end{array}$ & I \\
\hline S. italicus $\quad \therefore$ & . & Grape must & o \\
\hline S. italicus var. melibiosi & . & Digestive tract of man & 3 or more \\
\hline S. italicus var. melibiosi & . & Digestive tract of horse & 6 or more \\
\hline
\end{tabular}

at different loci, but we are not yet in a position to know whether they are biochemically identical. If they are identical entities, the possibility exists that they may have arisen through chromosome duplication or inversion. But whatever their origin, the fact remains that only a single polymeric gene is sufficient for the synthesis of the enzyme which governs the hydrolysis of the sugar in question. S. carlsbergensis, with its one Me-gene, ferments melibiose just as does the horse strain of $S$. italicus var. melibiosi, with its six or more Me-genes, while a genetic segregant of the horse strain containing only one Me-gene appears no less effective in fermenting melibiose than the original multigenic strain.

Since the standard system of classification of the yeast fungi (Lodder and Kreger-van Rij, I952) rightly places so much emphasis upon fermentative ability, it would seem that determination of the fermentative genotype would be a highly desirable undertaking for the future. From an ideal point of view, knowledge of the number and kinds of fermentative genes occurring in any particular yeast could be regarded as a valuable supplement to its diagnostic characters, since such genetic knowledge, if sufficiently embracing in scope, might be instrumental in the attainment of a more natural system of classification. However, the difficulties that are involved in such a project are well illustrated in the present study which, although laborious and detailed, 
yielded only preliminary factual knowledge of the genetics of melibiose fermentation in the two strains employed: the actual number and identity of the melibiase genes present have not been determined. When only one gene for a particular fermentative character occurs, the problem of isolating and identifying it is, of course, immeasurably simpler, but the increasing number of recorded instances in yeasts of polymeric genes leads one to the conclusion that their taxonomic value alone is not sufficient to justify the nearly insurmountable work required for their complete elucidation.

Finally, a word should be added on the subject of asci which yielded unexpected segregation ratios. For example, in the horse strain, 6 abnormal asci were obtained out of a total of $i 60$ analysed. This figure of less than 4 per cent. we consider to be an expression of the exceptions or abnormalities which are so frequently encountered in biological material and have accordingly made no attempt to investigate them further.

\section{SUMMARY}

A genetic investigation of Saccharomyces italicus var. melibiosi has revealed the presence of at least 3 polymeric melibiase genes in the strain isolated from the digestive tract of man and at least 6 polymeric melibiase genes in the strain isolated from the digestive tract of horse. Whether any of the genes from the one strain are identical with those of the other has not been determined.

Acknowledgments.-The authors wish to acknowledge with thanks the kindness of Dr van Uden in placing his cultures at their disposal, the interest shown by Professor Øjvind Winge in these investigations and his criticism of the manuscript, the technical assistance of Frøken Tove Lorentzen, and the assistance of Dr Gad Avigad in the chromatographic work.

\section{REFERENCES}

BLOCK, R. J., LE STRANGe, R., AND zWEIG, G. 1952. Paper chromatography, a laboratory manual. Academic Press, New York.

Ditlevsen, E. 1944. A case of simple segregation in Saccharomyces italicus. Compt. Rend. Lab. Carlsberg, Sér. Physiol., 24, 31-37.

FOWELL, R. R. 1952. Sodium acetate agar as a sporulation medium for yeasts. Nature, 170,578 .

GILLILAND, R. B. 1956. Maltotriose fermentation in the species differentiation of Saccharomyces. Compt. Rend. Lab. Carlsberg, Sér. Physiol., 26, 139-148.

Lindegren, C. C., SPIEgelman, s., AND Lindegren, G. 1944. Mendelian inheritance of adaptive enzymes in yeast. Proc. Natl. Acad. Sci., 30, 346-352.

LODDER, J., AND KREger-VAN RIJ, N. J. W. 1952. The yeasts. A taxonomic study. North Holland Publ. Co., Amsterdam.

LOSADA, M. 1957. The hydrolysis of raffinose by yeast melibiase and the fermentation of raffinose by complementary gene action. Compt. Rend. Lab. Carlsberg, Sér. Physiol., 25, 460-482.

SPIEGELMAN, s., LiNDEGREN, c. C., AND Lindegren, G. 1945. Maintenance and increase of a genetic character by a substrate-cytoplasmic interaction in the absence of the specific gene. Proc. Natl. Acad. Sci., 3I, 95-102.

SPIEGELMAN, s., AND DUNN, R. 1947. Interactions between enzyme-forming systems during adaptation. 7. Gen. Physiol., 31, $153^{-1} 73$. 
SUOMALAinen, H., AXELSON, E., AND OURA, E. 1956. The interaction of zymohexoses and maltose in maltose fermentation by baker's yeast. Biochim. et Biophys. Acta, 20, 319-322.

VAN UDEN, N., AND ASSIS-LOPES, L. 1957. Fermentation of raffinose in the absence of invertase by Saccharomyces italicus Castelli var. melibiosi nov. var. Portug. Acta Biol., 4 (Sér. A), 323-327.

WINGE, Ø. 1935. On haplophase and diplophase in some Saccharomycetes. Compt. Rend. Lab. Carlsberg, Sér. Physiol., 21, 77-I I I.

WINGE, ø., AND ROBERTs, C. I949. A gene for diploidisation in yeasts. Compt. Rend. Lab. Carlsberg, Sér. Physiol., 24, 341-346.

WINGE, ø., AND ROBERTS, C. I957. A genetic analysis of melibiose and raffinose fermentation. Compt. Rend. Lab. Carlsberg, Sér. Physiol., 25, 419-459.

WTNGE, $\varnothing$, AND ROBERTS, C. 1958. Life history and cytology of yeasts, pp. 93-122 in The Chemistry and Biology of Keasts. Academic Press, New York. 


\section{Plate}

Fig. I.-Giant colonies of $\mathrm{H} 352$ and its parents, 5 I O-6 (left) and 303-9 (right).

FIG. 2.-Giant colony of the original human strain, 510.

FIG. 3.-Giant colonies of $\mathrm{H} 353$ and its parents, 5 I I-I I (left) and 303-9 (right).

FIG. 4.-Giant colony of the original horse strain, $5 \mathrm{II}$.

Fig. 5.-An isolated spore of $\mathrm{H} 366$ which has burst. Photographed in a wort droplet in the dissecting chamber. (ca. 2500 X.)

FIG. 6.-A colony composed of round-oval cells derived from a single spore of 5 Io. Photographed in a wort droplet in the dissection chamber. (ca. $1500 \times$.)

Fig. 7.-A colony composed of long cells derived from a single spore of $5_{1}$ Io. Photographed in a wort droplet in the dissecting chamber. (ca. $1500 \times)$. 

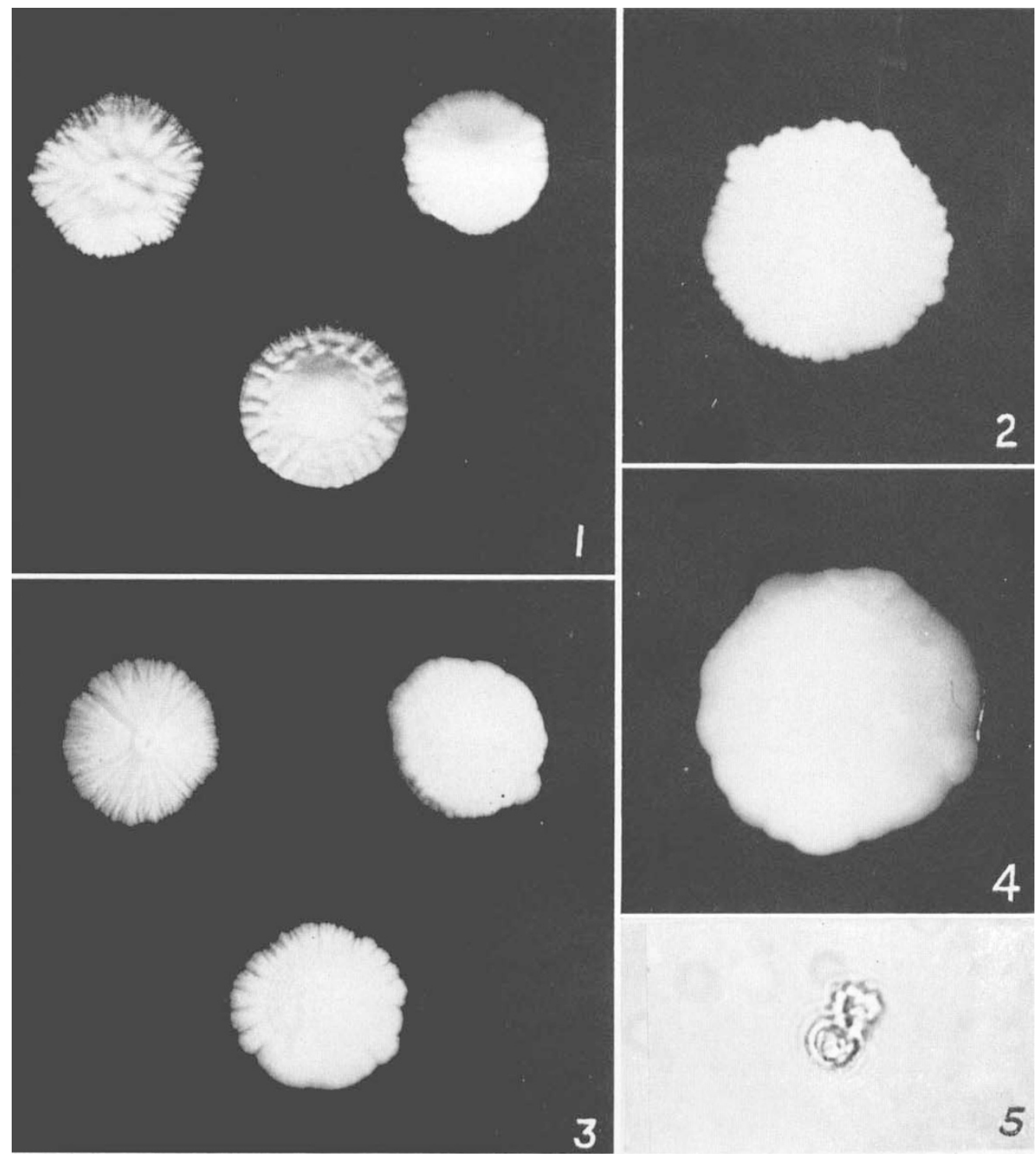

3
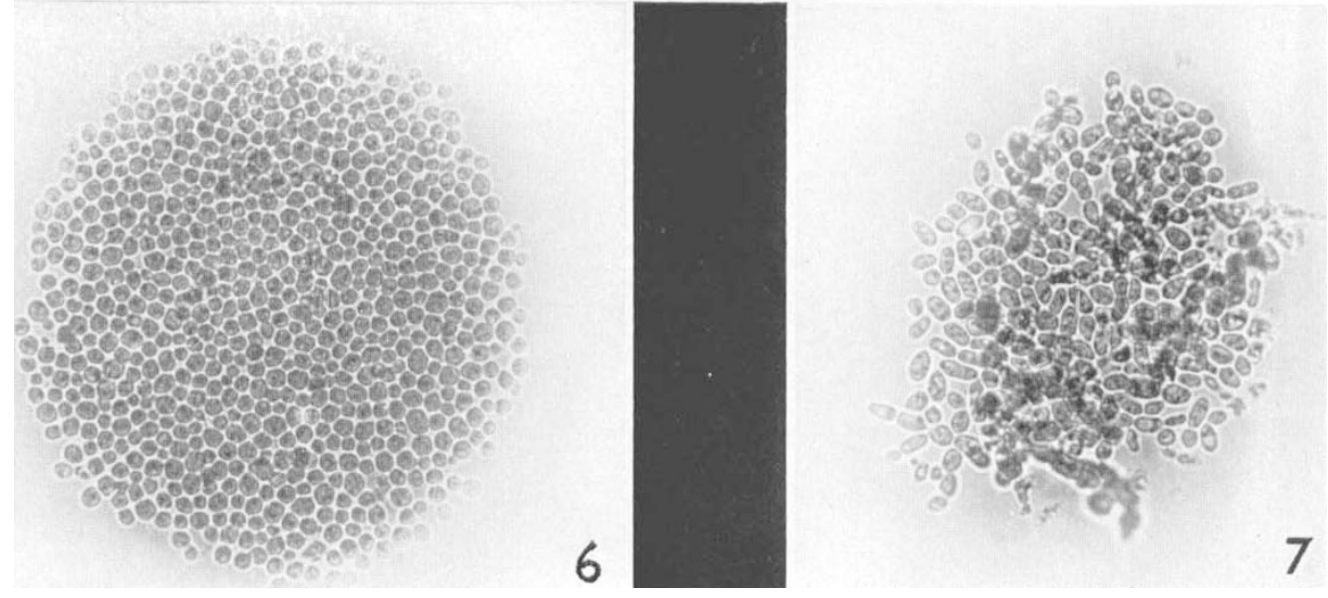